\title{
Causality between Non-Oil Export, Financial Sector Development and Economic Growth: Evidence from Nigeria
}

\author{
Emmanuel S. Akpan', Eleazar C. Nwosu' ${ }^{2}$, Gamaliel O. Eweke ${ }^{1}$ \\ ${ }^{1}$ Department of Accounting \& Finance, Federal University Otuoke, Yenagoa, Nigeria \\ ${ }^{2}$ Internal Audit Unit, Federal Polytechnic, Ukana, Nigeria \\ Email: bushdukakis07@gmail.com, chimeenwosu@yahoo.com, apache664@gmail.com
}

How to cite this paper: Akpan, E.S., Nwosu, E.C. and Eweke, G.O. (2017) Causality between Non-Oil Export, Financial Sector Development and Economic Growth: Evidence from Nigeria. Journal of Mathematical Finance, 7, 39-53.

https://doi.org/10.4236/jmf.2017.71002

Received: November 27, 2016

Accepted: January 8, 2017

Published: January 11, 2017

Copyright $\odot 2017$ by authors and Scientific Research Publishing Inc. This work is licensed under the Creative Commons Attribution International License (CC BY 4.0).

http://creativecommons.org/licenses/by/4.0/

\begin{abstract}
This study examined the causality between non-oil export, financial sector development and economic growth in Nigeria. The study employed credit to private sector, total bank deposit, prime lending rate, market capitalization, money market instruments as proxy to measure financial sector development, while GDP was used to capture economic growth, using annual data from 1985 to 2015. All the variables were stationary at first difference using the Augmented Dickey Fuller (ADF) and Phillip Perron (PP) tests. The Johansen Cointegration test result showed that a long-run relationship between non-oil export, financial sector development and economic growth existed. The Granger causality test indicates that a bi-directional causality runs from total bank deposit, credit to the private sector and market capitalization to economic growth. Also, a unidirectional causality existed between prime lending rate and economic growth. The study shows that out of the five proxy for financial sector development, three showed significant causality with economic growth. These findings therefore imply that a bi-directional relationship exists between financial sector development and economic growth, indicating that a growth in the financial sector will cause same in the economy and vice versa. Finally, the study recommends that the government formulate policies that will enhance credit to the private sector, such as not operating the Treasury Single Account (TSA) Policy in a holistic manner, so that banks will have fund to propel their credit delivery function effectively; considering the fact that the public sector drives the Nigerian economy as it stands now. However for capital market development, investors protection policies should be enhanced in order to strengthen and improve public confidence in the capital market, such as reducing charges for the purchase and sale of securities and reduction of listing requirements for new companies on the exchange.
\end{abstract}


Keywords

Non-Oil Export, Financial Sector Development and Economic Growth

\section{Introduction}

In this study, we explore the nexus between non-oil export, financial sector development and economic growth. For decades now the major driver of the Nigerian economy has been crude oil, as the economy has been adjudged the 6th largest exporter in the world [1]; however, with the latest nose dive in the price of crude oil in the global market and the action taken by the US in boycotting her crude. It becomes imperative that other means of revenue generation needed to be explored to save her ailing economy. As opportunities present themselves in the non-oil export and financial sector.

Before the advent of crude oil as a major income earner to the economy, non-oil export was the major revenue backbone as it accounted for over $74 \%$ of the total revenue for the country. As at 1970, the total output of major agricultural commodities was at 6,461,000 tons. By 1985, the contribution of non-oil export to total revenue fell to $23 \%$, with that of oil-revenue climbing to $73 \%$ [1]. This situation led to the formulation of the Structural Adjustment Programme (SAP) by the Babangidaregime, as a measure to remedy the poor performance of the non-oil export sector, as policies were enacted to revive the ailing agricultural sector in the country.

Likewise, the financial sector plays a vital role in economic growth and development as it channels resources from area of surpluses to those of deficit in the economy. Its liquidity role stands the most significant, as the major players consists of the Central Bank of Nigeria, commercial banks, capital markets, discount houses, insurance companies, asset management companies and pension houses. In recent years, the sector has witnessed major reforms to enhance its performance, notably the deregulation of the banking system. Conventional wisdom holds an interaction exists between financial sector and economic growth exists, as a vibrant financial sector will lead to a growth of the Nigerian economy. It is against this back drop, that major economies of the world strive to develop their financial sector so as to achieve sustainable economic growth.

This study is a follow up of a previous work on Nexus between Oil Revenue, Non-Oil Export and Industrial Output in Nigeria: An Application of the VAR Model [1]. A new insight to cover a more recent data set, as regards time series was adopted, in order to ascertain the nature of the causal relationship existing among the variables in Nigeria.

\section{Review of Literature}

Earlier and contemporary studies on non-oil export, financial sector development and Economic growth have been reviewed for better understanding. 


\section{Non-Oil Export and Economic Growth}

From the traditional Keynesian theory, an increase in exports is one of those factors that can cause an increase in demand and thus will certainly bring about increase in outputs, all other things being equal [2]. The export-led growth hypothesis postulates that exports are a main determinant of economic growth and the arguments here are as follows: first, that the export sector generates positive externalities on non-export sectors through more efficient management styles and improved production techniques [3]. Second, export expansion increases productivity by offering potential for scale economies [4] [5]. Third, exports alleviate foreign exchange constraints and provide greater access to international markets [6].

[7] examined the export and economic growth nexus in Indonesia from 1971 to 2008. They investigated such relationship in a time series framework using the vector autoregressive (VAR) model. Based on findings of causality analysis conducted in VECM (Vector Error Correction Model) system, they concluded that exports and economic growth exhibits bi-directional causal structure, which is ELG in long-run and GLE in short run. [8] investigated the causal relationship between non-oil international trade and the GDP in a panel of 11 selected oil exporting countries by using panel unit root tests and panel co-integration analysis. A three-variable model was formulated with oil revenues as the third variable. Their results showed a strong causality from oil revenues and economic growth to trade in the oil exporting countries, while non-oil trade showed no significant effect on GDP in short and long-run.

[9] applied the Granger causality test to empirically determine the relationship between exports and economic growth in South Africa from 1964-1993. The evidence of his study indicates that exports and economic growth are co-integrated, which confirms the existence of a long run relationship between the two variables. In addition, the evidence seemed to verify the notion that economic growth Granger-causes export growth, but failed to support the export-led hypothesis that export growth causes economic growth. [10] investigated export-led-growth by time series econometric techniques (unit root test, cointegration and Granger causality through vector error correction model) over the period of 1970 to 2008 for Pakistan. The results of the study reveal that export expansion leads to economic growth.

In the Nigerian context some studies conducted were not quite different from the above studies. [11] studied non-oil exports and economic growth in Nigeria with emphasis on the agricultural sector and mineral resources using OLS (Ordinary Least Square) and co-integration analysis, found that non-oil exports have performed below expectations. [12] used the augmented production function (APF) and endogenous growth model (EGM) in evaluating the effect of non-oil export on economic growth in Nigeria. Their findings indicate a very weak and infinite impact of non-oil export on economic growth in Nigeria. [13] using the VECM model explored the long-run implications of industrial production and non-oil export on economic growth in Nigeria from 1970-2006, they 
found that causality runs from economic growth to non-oil export.

[14] used co-integration test and Granger causality test in investigating the causal link between non-oil exports and economic growth in Nigeria. Their findings suggest that government must diversify the production base of the economy, promote non-oil exports, and build up a viable service infrastructure to drive private domestic and foreign investment. [15] used the OLS method involving error correction model to investigate the effect of non-oil export on economic growth in Nigeria, found that the effect of non-oil export impacted positively by $26 \%$ on the productive capacity of goods and services in Nigeria during the period.

[16] in his studies employed econometric methodologies to assess the impact of oil export and non-oil export on the growth of Nigerian economy and discovered that there is a unidirectional causality from oil export to GDP which goes to support the export-led-growth in the case of Nigeria but with reference to oil sector only. He also found non-oil export does not Granger cause economic growth in Nigeria. Okafor, [17] using the Ordinary Least Square Method, revealed that the impact of non-oil export on the economic growth was significant and positive as a unit increase in non-oil export caused a $43 \%$ increase in the productive capacity of goods and services in Nigeria during the period.

[18] examined the relationship between non-oil sector and economic growth from 1980-2012, using co-integration and Error Correction Model (ECM) and observed a significant relationship between non-oil export variable and economic growth. [19] employed multiple regression in testing the linear relationship between the Non-Oil Export and GDP in Nigeria from 1989 to 2008. His findings revealed that Nigeria non-oilexport has some significant contribution on economic growth.

[20] used the ordinary least square (OLS) regression technique emphasized that the contributions of the non-oil sector export to the GDP in Nigeria is still marginal and almost insignificant. [21] also discovered using various econometric method in his research for Nigeria covering the period from 1991-2008 recorded that the inefficient performance of the non-oil marketing of board deterred progress of the non-oil sector.

[11] analyzed the effectiveness of Nigeria's export promotion strategies in diversifying the productive base of the Nigerian Economy from Crude oil as the major source of foreign exchange. Time series data ranging from 1981 to 2010 and regression analysis was adopted. Findings from the study reveal that nonoil exports have performed weakly. [22] examined the impact of non-oil export strategies on economic growth in Nigeria from 1970 to 2013 using regression analysis. it was observed that non-oil export has positively affected economic growth in Nigeria.

\section{Financial Sector Development and Economic Growth}

Scholars such as [23] [24] [25] [26] had emphasized the importance of financials system in economic growth. [27] contends that the industrialization process in England was as a result of the development of the financial sector which in- 
creased government and people access to funds that were used to finance capital project which necessitated the development of the economy.

[28] examined the effect of financial sector development in Nigeria from 1980 to 2000 using the OLS technique. The result showed a positive relationship between economic growth in Nigeria and all the capital market development variables used. The findings showed that $98 \%$ of the variation in economic growth is caused by the explanatory variables based on his findings. [29] examined the relationship between financial sector development and economic growth for 35 developing countries from 1970-2003. Using the GMM (Generalized Method Moment) technique, they observed that financial sector development affects per capital GDP mainly through its role in efficient resource allocation rather than its effect on capital accumulation.

[30] studied the relationship between financial sector development and economic growth in Zimbabwe from 1980-2006. The cointegration and multivariate Granger causality technique adopted showed a unidirectional causality from economic growth to financial development. [31] examined the impact of financial sector development on economic growth in Fiji. The ARDL (Autoregressive Distributed Lag) and cointegration technique were used, the results showed the presence of a long-run relationship with linkage from domestic private sector credit to economic growth but not vice-versa. Their result further indicated evidence of a bi-directional short-run causality between the variables suggesting that private sector credit not only promoted economic growth, but also affected trade balance.

[32] examined the relationship between financial sector development, economic growth and poverty reduction in Nigeria covering the period of 1970-2011. The Autoregressive Distributed Lag model (ARDL) and Toda and Yamamoto No causality test, technique was adopted. The results of the study revealed that financial sector development does not cause poverty reduction and that economic growth causes financial sector growth. [33], investigated the relationship between the development of financial market and economic growth in Kenya during 1970-2008 using an expanded neoclassical growth model and ARDL technique. The findings suggest that development of the financial sector, especially the size of banking sector, leads to enhanced economic growth.

[34] examined the impact of financial sector development on economic growth in Zimbabwe from 1995 to 2008. The Granger causality and cointegration technique applied showed that economic growth Granger causes financial sector development and there are positively related in the long run. [35] used annual data for the period 1978-2007, using Granger test based on Vector Error Correction Model (VECM) showed that a relationship runs from economic growth to financial sector development in Greece.

[36] examined the financial sector development-economic growth nexus in Nigeria with annual dataset covering the period, 1980-2000. The co integration/Error Correction Mechanism (ECM) adopted showed that there is a positive effect of financial sector development on economic growth in Nigeria. By 
employing cross-section data analysis during the period 1960 to 1999 for 159 countries, [37] examined the relationship between financial sector development and economic growth. They adopted the two-stage least squares (2SLS) to address the problem of potential endogeneity in the underlying relationship. The results of their study indicated that financial sector development has a positive and statistically significant effect on economic growth.

[38] examined the relationship between financial sector development and economic growth in Kenya from 1970 to 2013. The autoregressive distributed lag (ARDL) technique applied revealed that financial sector development exerts a positive and statistically significant effect on economic growth in Kenya. [30] examine the relationship between financial sector development and economic growth in Nigeria from 1970-2009, using Granger causality tests. The findings suggest bidirectional causality between financial sector development and economic growth in Nigeria.

[40] empirically investigated financial sector development and economic growth in Nigeria. Using the Ordinary Least Squares (OLS) method. The findings showed that financial sector development has a substantial positive effect on economic growth in Nigeria. [41] investigated the impact of financial sector development variables on economic growth in Nigeria, using time series data for the period 1960-2008. The study utilized the co-integration technique, causality test and error correction mechanism. The results showed that money supply and credit to private sector positively impacted on economic growth in Nigeria and were as well co-integrated with GDP for the study period. While the Granger test shows a bi-directional causality existing between GDP and all the explanatory variables.

[42] investigated the nexus between financial sector development and economic growth in South Africa, from 1975-2010. Adopting the cointegration and error correction modelling and; the Granger causality tests. The results of the study showed that economic growth is explained by the financial sector variables. The Granger causality test results show that there is generally a bidirectional relationship between economic growth and financial sector development which implies that if the economy grows the financial services sector also grows and vice versa. [43] examined the linkage between financial sector development and economic for the period 1990 to 2010. The study employed Vector Error Correction (VEC) and co-integration technique. The findings suggest a strong positive relationship between financial sector and economic growth.

It is quite evident from empirical literature that there is a relationship between financial sector development and economic growth, however, this relationship varies among countries mainly because of factors such as regulation, level of government participation in the economy, trade openness level of income, time periods etc. However, according to [44] there is no consensus to whether financial development spurs economic growth.

Finally, it can be observed from the above studies that none considered a multivariate causality between non-oil export, financial sector development and 
economic growth. This study therefore adopts the multivariate causality approach to test for the relationship among the variables.

\section{Methodology}

The study utilized annual time series data for the period 1985-2015, obtained from various issues of Central Bank of Nigeria (CBN) Statistical Bulletin. The data collected include five variables as measures of financial sector development such as stock market capitalization, credit to the private sector, total bank deposit, prime interest rate and value of money market instruments, all scaled to GDP. Also Non-oil export data was measured using available data on the value of non-oil trade scale to GDP. Lastly, GDP was used as a proxy for economic growth. Table 1 gives a brief description of the variables.

This study adopts the cointegration technique while the Granger causality methodology was used to analyze the data. The Augmented Dickey Fuller (ADF) and Philips Perron (PP) unit root test was used to access the stationarity and order of integration. The Johansen cointegration technique was employed to check for the existence of a long-run equilibrium relationship among the variables, since it has the advantages amongst others for allowing for more than one cointegration equation. While the error correction model will allow us access the various magnitudes. Finally, the Granger Causality test will be used to determine the causal relationship among the variables.

The model adapted for the study is specified below:

$\mathrm{GDP}=\beta_{0}+\beta_{1} \mathrm{CPS}+\beta_{2}$ LENDRATE $+\beta_{3} \mathrm{DEP}+\beta_{4} \mathrm{MKTCAP}+\beta_{5} \mathrm{MONIMKT}+$ $\beta_{6}$ NONOILEXP $+\mu_{t} \beta_{1} \beta_{3} \beta_{4} \beta_{5}>0 ; \beta_{2}<0$

where:

$$
\begin{aligned}
& \beta_{0}=\text { Constant } \\
& \beta_{1} \beta_{2} \beta_{3} \beta_{4} \beta_{5} \beta_{6}=\text { Regression Coefficients } \\
& \text { GDP }=\text { Gross Domestic Product } \\
& \text { CPS }=\text { Credit to the Private Sector } \\
& \text { LENDRATE = Prime Interest Rate }
\end{aligned}
$$

Table 1. Data description.

\begin{tabular}{ccl}
\hline \multicolumn{1}{c}{ Variables } & Abbreviation & \multicolumn{1}{c}{ Description } \\
\hline Gross Domestic Product & GDP & $\begin{array}{l}\text { The monetary value of all finished goods and services manufactured within a } \\
\text { country at a particular period. }\end{array}$ \\
Credit to the Private Sector & CPS & $\begin{array}{l}\text { This refers to funds such as loans, trade credits and other account receivables } \\
\text { granted to the private sector by banks. }\end{array}$ \\
Prime Interest Rate & LENDRATE & It is the interest rate commercial banks charge their most trustworthy clients. \\
Total Bank Deposit & DEP & The total amount of funds placed in the banking sector. \\
Stock Market Capitalization & MKTCAP & Total market value of all shares outstanding. \\
Value of Money Market Instruments & MONIMKT & The total value of all short-term securities and debt sold on the money market. \\
Non-Oil Export & NONOILEXP & The total value of non-oil revenue. \\
\hline
\end{tabular}

Source: Author’s 2015 
DEP $=$ Total Bank Deposit

MKTCAP = Stock Market Capitalization

MONIMKT $=$ Total Value of Money market Instrument

NONOILEXP $=$ Total Value of Non-Oil Export

$\mu_{t}=$ Error term

\section{Results and Discussion of Findings}

\subsection{Unit Root Test}

Stationarity in time series implies that the mean, variance and covariance are constant across different periods. This study tested for the stationarity of all variables used by applying two different unit root test namely; the Augmented Dickey-Fuller (ADF) and Phillips-Perron (PP) test.

According to Table 2, all variables for non-oil export, financial sector development and economic growth attained stationarity after first differencing with a significance at $1 \%$ level, indicating that all variables are integrated of order 1(1). Therefore, the null hypothesis of unit root can be rejected.

\subsection{Co-Integration Test}

Since all variables are stationary and integrated of the same order, the next step is to check if a long-run relationship exist among the variables. A co-integration test was performed using the Johansen co-integration technique to check for the existence of a long-run relationship.

From Table 3, the Trace statistic, Max-eigenvalue and MacKinnon-HaugMichelis (1999) p values, reveals 2 and 1 ranks in the trace and max-eigenvalues criteria respectively, thereby leading us to reject the null hypothesis of no cointegration equation among the variable at 5 per cent. The econometric results therefore indicate that a long-run relationship exists between non-oil exports, financial sector development and economic growth. The implication of these findings is that non-oil export, financial sector development and economic growth are cointegrated, that is they move together in the long run. This result allows for the estimation of the VECM (Vector Error Correction Model).

Table 2. Unit root test results.

\begin{tabular}{|c|c|c|c|c|c|}
\hline \multirow{2}{*}{ Variables } & \multicolumn{2}{|c|}{ ADF TEST } & \multicolumn{2}{|c|}{ PHILLIPS - PERRON TEST } & \multirow[b]{2}{*}{ Order of Integration } \\
\hline & Levels & First Difference & Levels & First Difference & \\
\hline CPS & -1.89470 & $-5.43148^{\star}$ & -1.68413 & $-5.27189^{\star}$ & $1(1)$ \\
\hline DEPOSIT & -2.07290 & $-4.25923^{\star}$ & -1.74397 & $-4.12376^{\star}$ & $1(1)$ \\
\hline LENDRATE & 1.23284 & $-4.86361^{\star}$ & 1.84019 & $-5.52934^{*}$ & $1(1)$ \\
\hline GDP & -1.86995 & $-4.06844^{\star}$ & -1.52553 & $-5.40077^{\star}$ & $1(1)$ \\
\hline MKTCAP & -1.86705 & $-4.19956^{\star}$ & -1.92287 & $-5.69989^{\star}$ & $1(1)$ \\
\hline MONIMKT & $-2.91013^{\star * *}$ & $-4.17181^{\star}$ & -1.81410 & $-6.49116^{\star}$ & $1(1)$ \\
\hline NONOILEXP & -2.68990 & $-4.96928^{\star}$ & $-3.86627^{* * *}$ & $-9.37226^{*}$ & $1(1)$ \\
\hline
\end{tabular}

$* /^{* *} / * * *$, indicates significance at $1 \%, 5 \%$ and $10 \%$ respectively; Source: Author's Computation Using Eviews 8. 
Table 3. Johansen co-integration test results.

\begin{tabular}{cccccccc}
\hline Hypothesized & \multicolumn{3}{c}{ Trace 0.05} & \multicolumn{3}{c}{ Max-Eigen 0.05} \\
\hline No. of CE(s) & Eigenvalue & Statistic & Critical Value & Prob. ${ }^{* *}$ & Statistic & Critical Value & Prob. ${ }^{* *}$ \\
\hline None $^{*}$ & 0.909336 & 169.2950 & 125.6154 & 0.0000 & 69.61734 & 46.23142 & 0.0000 \\
At most 1* & 0.697329 & 99.67771 & 95.75366 & 0.0261 & 34.65815 & 40.07757 & 0.1798 \\
At most 2 & 0.680058 & 65.01956 & 69.81889 & 0.1138 & 33.04884 & 33.87687 & 0.0625 \\
At most 3 & 0.381495 & 31.97072 & 47.85613 & 0.6138 & 13.93305 & 27.58434 & 0.8272 \\
At most 4 & 0.317106 & 18.03767 & 29.79707 & 0.5633 & 11.06107 & 21.13162 & 0.6412 \\
At most 5 & 0.196808 & 6.976598 & 15.49471 & 0.5804 & 6.355691 & 14.26460 & 0.5680 \\
At most 6 & 0.021183 & 0.620907 & 3.841466 & 0.4307 & 3.841466 & 3.84166 & 0.4307 \\
\hline
\end{tabular}

Source: Author's Computation Using Eviews 8.

\subsection{Error Correction Model}

Given the fact that the variables in the equation are cointegrated, the next step is the estimation of the short-run dynamics within a vector error correction model (VECM) in order to capture the speed of adjustment to equilibrium in the case of any shock to any of the independent variables. The error-correction term shows the adjustments of the model from short-run disequilibrium to long-run equilibrium trends.

From Table 4, the over parameterized error correction model $\left(\mathrm{ECM}_{\mathrm{t}-1}\right)$ is well specified and is of the expected negative sign and significant with GDP. The coefficient of the error correction term indicates that about $31.8 \%$ percent of the disequilibrium in the long run is offset by the short-run adjustment within a year. This implies a low speed of adjustment.

Furthermore, the ECM model indicates that the value of prime interest rate (LENDRATE) has a negative and significant impact on GDP, suggesting that an increase in LENDRATE by N1 will reduce GDP by $2.92 \%$ holding the influence of other variables constant. Also, there is a positive and significant relationship between total bank deposit (DEP) and GDP, indicating that a rise in DEP by N1 will lead to an increase in GDP by $36.93 \%$. Similarly, a positive and significant relationship exist between credit to the private sector (CPS) and GDP; but wiping out the influence of other regressors on GDP, will cause GDP to rise by $48.83 \%$ when CPS is increased by N1. Likewise, a significant and positive relationship was observed between market capitalization (MKTCAP) and GDP, therefore an increase in MKTCAP by N1 holding other explanatory variables constant will make GDP rise by $49.84 \%$. Finally, Non-oil Export (NOILEXP) and Value of Money Market Instrument (MONIMKT) were not significant with GDP.

The adjusted $\mathrm{R}^{2}$ of 0.520600 shows a fairly good fit, indicating that about $52.06 \%$ of variations in the dependent variable (GDP) are explained by the cumulative effects of the explanatory variables. While the standard error of 0.066412 signifies that about $6.64 \%$ of the variation in the dependent variable will not be explained by the explanatory variables. The F statistics of 2.754563 
Table 4. Overparametized ECM result.

\begin{tabular}{ccccc}
\hline Dependent Variable: GDP & \multicolumn{4}{c}{} \\
\hline & Coefficient & Std. Error & t-Statistic & Prob. \\
\hline LENDRATE (-1) & -0.029266 & 0.020446 & -1.431345 & 0.0486 \\
DEP (-1) & 0.369343 & 1.504412 & -0.245507 & 0.0087 \\
CPS (-1) & 0.488304 & 0.670049 & 0.728758 & 0.0350 \\
MKTCAP (-1) & 0.808407 & 0.272519 & 2.966423 & 0.0079 \\
MONIMKT (-1) & 1.692828 & 1.109589 & 1.525636 & 0.1436 \\
NOILEXP (-1) & 0.498372 & 0.833737 & 0.597756 & 0.4371 \\
C & 0.059963 & 0.037525 & 1.597965 & 0.1265 \\
ECM (-1) & -0.318092 & 0.026781 & -1.187756 & 0.0001 \\
R-squared & 0.566122 & Mean dependent var & 0.098103 \\
Adjusted R-squared & 0.520600 & S.D. dependent var & 0.083054 \\
S.E. of regression & 0.066412 & Akaike info criterion & -2.319080 \\
Sum squared resid & 0.083800 & Schwarz criterion & 1.847599 \\
Log likelihood & 43.62667 & Hannan-Quinn criter. & -2.171418 \\
F-statistic & 2.754563 & Durbin-Watson stat & 2.024850 \\
Prob(F-statistic) & 0.030138 & & & \\
\hline
\end{tabular}

Source: Author's Computation Using Eviews 8.

indicates that the model significant at $5 \%$ level and is a good fit. While the Akaike and Schwarz criterion shows correct specification of the model.

\subsection{Granger Causality Test}

To determine the direction of the causality between non-oil export, financial sector development and economic growth, Granger causality test was performed.

According to Table 5, the results suggest that LENDRATE does not Granger cause GDP, while GDP Granger cause LENDRATE, indicating a unidirectional relationship. This indicates that an increase in economic growth (GDP) will cause a response in prime lending rate (LENDRATE), but not the other way round.

Furthermore, the results suggest that CPS does Granger cause GDP, likewise GDP does Granger cause CPS. So the causality is bidirectional because the two variables do Granger cause each other. This means that if credit to the private sector (CPS) increases, economic growth (GDP) will be affected, and vice versa. Likewise, the relationship between DEP (total bank deposit) and GDP runs both ways, indicating a bidirectional causality. This therefore suggests that in the long run total banking sector deposits (DEP) will cause economic growth (GDP), and vice versa.

Also, a bi-causal relationship between MKTCAP and GDP existed, as the null hypothesis was rejected. This indicates that an increase in the market capitalization (MKTCAP) will cause a response in economic growth (GDP), and vice ver- 
Table 5. Granger causality test results.

\begin{tabular}{cccc}
\hline Null Hypothesis: & Obs & F-Statistic & Prob. \\
\hline LENDRATE does not Granger Cause GDP & 30 & 0.38015 & 0.5427 \\
GDP does not Granger Cause LENDRATE & & 2.76555 & 0.1029 \\
DEP does not Granger Cause GDP & 30 & 2.09530 & 0.0543 \\
GDP does not Granger Cause DEP & & 1.49728 & 0.0317 \\
CPS does not Granger Cause GDP & 30 & 6.30633 & 0.0143 \\
GDP does not Granger Cause CPS & & 3.54671 & 0.0705 \\
MKTCAP does not Granger Cause GDP & 30 & 0.04206 & 0.1041 \\
GDP does not Granger Cause MKTCAP & & 2.41481 & 0.0518 \\
MONIMKT does not Granger Cause GDP & 30 & 0.23557 & 0.6313 \\
GDP does not Granger Cause MONIMKT & & 0.00322 & 0.9552 \\
NOILEXP does not Granger Cause GDP & 30 & 0.05746 & 0.8124 \\
GDP does not Granger Cause NOILEXP & & 0.41324 & 0.5258 \\
\hline
\end{tabular}

Source: Author's Computation Using Eviews 8.

sa. Likewise, a bidirectional relationship was detected between value of money market instrument (MONIMKT) and GDP, showing that causality runs both ways between both variables. The findings therefore suggest that a growth in the value of money market instrument will cause a response in economic growth, and vice versa.

The results also accept the null hypothesis, as a bidirectional non-causal relationship was found between MONIMKT and GDP. This therefore shows a rise in the total value of money market instruments (MONIMKT) in the economy will not trigger economic growth, and vice versa. Finally, NOILEXP and GDP, indicated a bi-causal relationship in the long-run. The findings suggest that an increase in non-oil export will not Granger cause economic growth, and vice versa.

\section{Conclusion and Recommendations}

The study employed five indicators as proxy to measure financial sector development; credit to the private sector (CPS), total bank deposits (DEP), market capitalization (MKTCAP), value of money market instruments (MONIMKT) and Prime lending rate (LENDRATE).

The results of the causality test found that causality does run from CPS to GDP, and vice versa. Likewise, bidirectional causality was found between DEP and GDP. The findings therefore show that growth in credit to the private sector and total bank deposits causes economic growth, and vice versa. Also, a bi-causal relationship exists between MKTCAP and GDP, indicating an increase in MKTCAP will cause GDP, and vice versa. A unidirectional causality exists between LENDRATE and GDP, as GDP causes LENDRATE, but LENDRATE does not causes GDP, thereby indicating that a growth in GDP causes LENDRATE. Also, non bi-causal relationship was found to exist between MONIMKT, 
NOILEXP and GDP. The findings suggest that growth in the market capitalization (MKTCAP), total bank deposit (DEP) and credit to the private sector (CPS) will trigger economic growth, and vice versa.

The fact that the growth in market capitalization, total bank deposit and credit to the private sector influences economic growth. To fully realize the growth potentials of the economy, it is therefore imperative to remove all obstacles that could hinder the growth of capital market development and banking sector. As we recommend that the government formulate policies that will enhance credit to the private sector, such as not operating the Treasury Single Account (TSA) Policy in a holistic manner, so that banks will have fund to propel their credit delivery function effectively; considering the fact that the public sector drives the Nigerian economy as it stands now. Again, having banks whose aim will focus on enhancing development in the real sector of the economy is an imperative. In terms of capital market development, we recommend that investor's protection policies should be revisited in other to strengthen and improve public confidence in the capital market, such as reducing charges for the purchase and sale of securities, reduction of listing requirements for new companies on the exchange and establishment of an effective legal framework which will enhance speedy and satisfactory resolve of investment related dispute, thereby creating confidence among participants in the market, while attracting other potential investors.

Finally, the evidence of bidirectional causality between credit to the private sector, market capitalization, total bank deposits and economic growth indicates simultaneity between financial sector development and economic growth. The findings suggest that development of the financial sector cannot be overemphasized as it key to economic growth.

The study is dependent upon available Nigerian data sets and we therefore suggest the need for further study that will consider basically the Vector Error Correction Model, to reconcile the short-run behaviour of the variables in the model to their long run behaviour; with the consideration of an increased time frame.

\section{References}

[1] Riman, H.B., Akpan, E.S., Offiong, A.I. and Ojong, C.M. (2013) Nexus between Oil Revenue, Non-Oil Export and Industrial Output in Nigeria: An Application of the VAR Model. International Journal of Financial Economics, 1, 48-60.

[2] Lin, J.Y. and Li, Y. (2007) Exports and Economic Growth in China: A Demand-Oriented Analysis. Mimeo, Centre for Economic Research, Pekin University, Beijing.

[3] Feder, G. (1983) On Export and Economic Growth. Journal of Development Economics, 12, 59-73. https://doi.org/10.1016/0304-3878(83)90031-7

[4] Helpman, E. and Krugman, P.R. (1985) Market Structure and Foreign Trade: Increasing Returns, Imperfect Competition and International Economy. MIT Press, Cambridge, MA.

[5] Krugman, P.R. (1997) Growing World Trade: Causes and Consequences. Brooking 
Papers on Economic Activity, 1, 327-43.

[6] Olayiwola, K. and Okodua, H. (2013) Foreign Direct Investment, Non-Oil Exports and Economic Growth in Nigeria: A causality Analysis. Asian Economic and Financial Review, 3, 1479-1496.

[7] Rahmaddi, R. and Ichihashi, M. (2011) Exports and Economic Growth in Indonesia: A Causality Approach Based on Multivariate Error Correction Model. Journal of International Development and Cooperation, 17, 53-73.

[8] Mehrara, M. (2014) The Relationship between Non-Oil Trade and GDP in Petroleum Exporting Countries. International Letters of Social and Humanistic Sciences, 1, 63-70.

[9] Ukpolo, V. (1998) Export and Economic Growth in South Africa: Evidence fromCointegration and Granger Causality Test. The African Economic \& Business Review, 1, 1-5.

[10] Sami, U., Bedi, U.Z., Muhammad, F. and Asif, J. (2009) Cointegration and Causality between Exports and Economic Growth in Pakistan. Pakistan Economic and Social Survey, 5, 49-63.

[11] Adenugba, A.A. and Dipo, S.O. (2013) Non-Oil Exports in the Economic Growth of Nigeria: A Study of Agricultural and Mineral Resources. Journal of Educational and Social Research, 3, 403-418. https://doi.org/10.5901/jesr.2013.v3n2p403

[12] Onodugo, V.A., Ikpe, M. and Anowor, O.F. (2013) Non-Oil Export and Economic Growth in Nigeria: A Time Series Econometric Model. International Journal of Business Management \& Research, 3, 115-124.

[13] Akpan, E.S., Riman, H.B., Duke II, J. and Mboto, H.W. (2012) Industrial Production and Non-Oil Export: Accessing the Long-Run Implications on Economic Growth in Nigeria. International Journal of Economics and Finance, 4, 252-259. https://doi.org/10.5539/ijef.v4n2p252

[14] Olabanji, O.E. and Henri, O. (2013) Econometric Analysis of Export and Economic Growth in Nigeria. Journal of Business Management and Applied Economics, 2, 1 14.

[15] Abogan, O.P. Akinola, E.B. and Baruwa, O.I. (2014) Non-Oil Export and Economic Growth in Nigeria (1980-2011). Journal of Research in Economics and International Finance, 3, 1-11.

[16] Uche. M.O. (2009) Exports and Economic Growth in Nigeria: An Empirical Analysis. Nigerian Economic Society (NES), Ibadan, Oyo State.

[17] Okafor, E.I., Eje, G.C. and Nwafor, O.C. (2015) Post Deregulation Evaluation of Non-Oil Export and Economic Growth Nexus in Nigeria: An Empirical Analysis. Journal of Economics and Finance, 6, 53-59.

[18] Ogunjimi, O., Aderinto, E. and Ogunro, T. (2015) An Empirical Analysis on the Relationship between Non-Oil Export and Economic Growth in Nigeria. International Journal of Academic Research in Business and Social Sciences, 5, 68-78. https://doi.org/10.6007/IJARBSS/v5-i12/1931

[19] Usman, F. (2010) Non-Oil Export Determinants and Economic Growth in Nigeria (1985-2008). European Journal of Business and Management Sciences, 3, 124-146.

[20] Ogbonna, M. (2010) The Contributions of Non-Oil Export to the GDP of Nigeria. Lincoln Publishers, Asaba.

[21] Ozoudo, P.J. (2010) Reviving Nigeria's Non-Oil Sector for Economic Development. $C B N$ Economic and Financial Review, 35, 22-26.

[22] Nwachukwu, P.O. (2014) The Impact of Non-Oil Export Strategies on Economic Growth in Nigeria (1970-2013). Journal of Economics and Sustainable Develop- 
ment, 5, 65-69.

[23] Schumpeter, J.A. (1911) The Theory of Economic Development. Harvard University Press, Cambridge.

[24] Goldsmith, R.W. (1969) Financial Structure and Development. Yale University Press, New Haven.

[25] Shaw, E.S. (1973) Financial Deepening in Economic Development. Oxford University Press, New York.

[26] McKinnon, R.I. (1973) Money and Capital in Economic Development. The Brookings Institution, Washington DC.

[27] Hicks, J. (1969) A Theory of Economic History. Clarendon Press, Oxford.

[28] Osinubi, T.S. (2002) Does Stock Market Promote Economic Growth in Nigeria? http://sta.uwi.edu/conferences/financeconference/

[29] Ahmad, E. and Malik, A. (2009) Financial Sector Development and Economic Growth: An Empirical Analysis of Developing Countries. Journal of Economic Cooperation and Development. 30, 17-40.

[30] Godfrey, N. (2013) Financial Sector Development and Economic Growth: Evidence from Zimbabwe. International Journal of Economics and Financial Issues, 3, 435446.

[31] Jayaraman, T.K. and Choong, C. (2007) Financial Sector Development and Growth in Fiji: An Analysis of Credit Boom and Its Implications. The Asia Pacific Economic Journal, 5, 1-20.

[32] Dandume, M.Y. (2014) Financial Sector Development, Economic Growth and Poverty Reduction: New Evidence from Nigeria. Journal of the Faculty of Economics and Administrative Sciences, 4, 2-22.

[33] Kagochi, J.M. (2013) Financial Development and Economic Growth in Kenya: Evidence from Expanded Neoclassical Growth Approach. Asian-African Journal of Economics and Econometrics, 13, 117-131.

[34] Chisunga, D. (2015) Causal Relationship between Financial Sector Development and Economic Growth: A Case of Zimbabwe. IOSR Journal of Business and Management (IOSR-JBM), 17, 1-12.

[35] Vazakidis, A. and Adomopoulos, A. (2009) Financial Development and Economic Growth: An Empirical Analysis of Greece. American Journal of Applied Sciences, 6, 1410-1417. https://doi.org/10.3844/ajassp.2009.1410.1417

[36] Nkoro, E. and Uko, A.K. (2013) Financial Sector Development-Economic Growth Nexus: Empirical Evidence from Nigeria. American International Journal of Contemporary Research, 3, 87-94.

[37] Khan, S. M. and Senhadji, S. (2003) Financial Development and Economic Growth: An Overview. IMF Working Paper wp/00/209, International Monetary Fund, Washington DC.

[38] Kiprop, M.J., Kalio, A., Kibet, L. and Kiprop, S. (2015) Effect of Financial Development on Economic Growth in Kenya: Evidence from Time Series Analysis. European Journal of Business and Social Sciences, 3, 62-78.

[39] Odeniran, S.O. and Udeaja, E.A. (2010) Financial Sector Development and Economic Growth Empirical Evidence from Nigeria. Central Bank of Nigeria Economic and Financial Review, 48, 91-124.

[40] Adelakun, O.J. (2010) Financial Sector Development and Economic Growth in Nigeria. Department of Economics, Joseph Ayo Babalola University, Ikeji Arakeji.

[41] Osuji, C. and Chigbu (2012) An Evaluation of Financial Development and Eco- 
nomic Growth in Nigeria: A Causality Test. Department of Accounting, Banking and Finance, Delta State University Asaba Campus, Asaba.

[42] Sunde, T. (2012) Financial Sector Development and Economic Growth Nexus in South Africa. International Journal of Monetary Economics and Finance, 5, 64-75. https://doi.org/10.1504/IJMEF.2012.044467

[43] Ubaje, D.O. and Ubaje, H.E. (2014) Empirical Study of Financial Sector Development on Economic Growth in Nigeria (1990-2010). International Journal of Public Administration and Management Research, 2, 122-137.

[44] De Gregorio, J. and Guidotti, P.E (1995) Financial Development and Economic Growth. World Development, 23, 433-448.

https://doi.org/10.1016/0305-750X(94)00132-I

Submit or recommend next manuscript to SCIRP and we will provide best service for you:

Accepting pre-submission inquiries through Email, Facebook, LinkedIn, Twitter, etc. A wide selection of journals (inclusive of 9 subjects, more than 200 journals)

Providing 24-hour high-quality service

User-friendly online submission system

Fair and swift peer-review system

Efficient typesetting and proofreading procedure

Display of the result of downloads and visits, as well as the number of cited articles Maximum dissemination of your research work

Submit your manuscript at: http://papersubmission.scirp.org/

Or contact jmf@scirp.org 